\title{
STUDY OF INFLUENCE OF EFFLUENT ON GROUND WATER USING REMOTE SENSING, GIS AND MODELING TECHNIQUES
}

\author{
S. Pathak*, B.K. Bhadra, J.R. Sharma \\ Regional Remote Sensing Centre - West, NRSC/ISRO, Dept. of Space, Govt. of India \\ CAZRI Campus, Jodhpur 342 003, India - (s_pathak, jrsharma@ hotmail.com \& bkbhadra63@gmail.com) \\ WG IV/8
}

KEY WORDS: Remote Sensing, GIS, land Use, Change Detection, Pollution, Modelling

\begin{abstract}
:
The area lies in arid zone of western Rajasthan having very scanty rains and very low ground water reserves. Some of the other problems that are faced by the area are disposal of industrial effluent posing threat to its sustainability of water resource. Textiles, dyeing and printing industries, various mechanical process and chemical/synthetic dyes are used and considerable wastewater discharged from these textile units contains about high amount of the dyes into the adjoining drainages. This has caused degradation of water quality in this water scarce semi-arid region of the country. Pali city is located South-West, $70 \mathrm{Kms}$ from Jodhpur in western Rajasthan (India). There are four Common Effluent Treatment Plant (CETP) treating wastewater to meet the pollutant level permissible to river discharge, a huge amount of effluent water of these factories directly meets the into the river Bandi - a tributary of river Luni. In order to monitor the impact of industrial effluents on the environment, identifying the extent of the degradation and evolving possible means of minimizing the impacts studies on quality of effluents, polluted river water and water of adjoining wells, the contamination migration of the pollutants from the river to ground water were studied.
\end{abstract}

Remote sensing analysis has been carried out using Resourcesat -1 multispectral satellite data along with DEM derived from IRS P5 stereo pair. GIS database generated of various thematic layers viz. base layer - inventorying all waterbodies in the vicinity, transport network and village layer, drainage, geomorphology, structure, land use. Analysis of spatial distribution of the features and change detection in land use/cover carried out. GIS maps have been used to help factor in spatial location of source and hydrogeomorphological settings. DEM \& elevation contour helped in delineation of watershed and identifying flow modelling boundaries. Litholog data analysis carried out for aquifer boundaries using specialized software. Establishment of other boundary conditions was based on well data. Calibration and validation of was done using ground water modelling software. Change detection analysis indicated areas of impact on land use/ cover particularly, agriculture activity. Normalised difference vegetation index found to have negative correlation with pollution level. Population dynamics have been studied and it is found to be poorly correlated with land degradation. Water levels do not show significant variations in past twenty years baring normal seasonal fluctuation. Chemical analysis of ground water samples studies in time series. The water quality studied through various parameters shows concentration in mid-reach of the Bandi river. Analysis of litholog data shows three unconfined aquifers. Pump test and resistivity survey was carried out for initial aquifer properties in local water levels. Modelling contaminant migration helped in prediction of the extent of the adversity. Surface flow is checked allowing more water but it is proving to be accumulation point in absence of good rainfall \& flow in the river. Hotspots of dumping /active contamination were identified with certain remediation efforts and supply of solid waste to cement industry in addition to bio-filter for heavy metals.

\section{INTRODUCTION}

\subsection{Overview}

The study area lies in arid zone of India having very scanty rains and very low ground water reserves. Competing with domestic uses water for irrigation and industries, ground water is important part of hydrological cycle. Some of the other problems that are faced by the area are disposal of industrial effluent posing threat to its sustainability of water resource. In textiles, dyeing and printing industries, various mechanical process and chemical/synthetic dyes are used and considerable wastewater discharged from these textile units contains high amount of the dyes into the adjoining drainages. Thus, industrial waste is prime source of ground water contamination.

* Suparn Pathak, Scientist/Engr. "SF", NRSC

\subsection{Source of contaminant}

Basically, dyes and pigments use organic material - highly structured \& difficult to decompose biologically, besides some inorganic metal oxides in fibre substance are also used after treating them with water soluble salts. Additionally, some vat dyes \& azoic pigments containing metal (especially $\mathrm{Cu}$ ) for printing are used in soluble form.

The diazotisation process - treating amine group with nitrous acid followed by coupling amino compound under favourable $\mathrm{pH}$ or applying insoluble dye on cotton by forming colour pigment inside fibre, requires treatment with $\mathrm{NaOH}$ (for Naphtholate) and later fast base is added, wastewater is flushed out. Bleaching \& finishing are other process using chemicals. Other than textile the polluted ground water irrigation return flow also increases its concentration. 
Industries : Out of 3422 registered industries in Pali City, 289 textile Industries along the Madiya road are under red category. Total water requirement in these industries is estimated at 41.833 MLD.

Common Effluent Treatment Plants (CETPs) : Treating wastewater to meet the pollutant level permissible to river discharge, a huge amount of effluent water of these factories directly meets the into the river Bandi - a tributary of river Luni. Since 1983, four CETPs with a capacity to treat 31.68 MLD of industrial effluent have been installed. Two CETPs were established in Pali-Mandiya road on the bank of Bandi River. CETP-III \& IV were established on Punayta road, in the west of Pali. The CETPs are managed and maintained by the Pali Water Pollution Control \& Research Foundation (PWPCRF) Trust, which is one of the very first co-operative pollution control measures in the country catering around 500 industries, these plants are generating liquid waste (12-13 MLD) and solid waste (13 tons/day). The average flow measured at individual CETP units is of the order of 3-12 MLD.

Pali city is located South-West, $70 \mathrm{Kms}$ from Jodhpur in western Rajasthan (India). It has three major industrial zones. While phase I\&II are located in North phase III lies at the bank of river Bandi. The study area falls in the Luni basin and is mainly drained by Sukri, Bandi, Luni, Guhiya, Rediya rivers and their tributaries. These streams are mostly ephemeral in nature and flow during rainy season. Durational variation in maximum temperature ranges from $15.2^{\circ} \mathrm{C}$ to $46.9^{\circ} \mathrm{C}$. While minimum temperature ranges from $0.3^{\circ} \mathrm{C}$ to $31.6^{\circ} \mathrm{C}$. The average annual rainfall of the area is around $452 \mathrm{~mm}$.

In order to monitor the impact of industrial effluents on the environment, identifying the extent of the degradation and evolving possible means of minimizing the impacts studies on quality of effluents, polluted river water and water of adjoining wells, the contamination migration of the pollutants from the river to ground water were studied.

\subsection{Review of literature}

The groundwater has turned alkaline and total dissolved solids, chloride, sulphate, sodium are very high in the groundwater rendering wells in the area unfit for drinking and even for irrigation. The soil in this area has also become hard and unfertile. In many sites heavy metals were also found (CGWB, 2004). A detailed chemical analysis of the effluents in the river water and groundwater from the dug well / tube well carried out, lying close to Bandi river from Pali city to Nerda dam on a distance of $50 \mathrm{~km}$ in the downstream direction (CSE, 2006). Heavy metal can be retained by soil through many processes including complex sorption and precipitation but metal sorption is highly dependent on $\mathrm{pH}$ (Buselli et.al, 1998). Average number of wells contaminated is 68 and around 13500 ha land is affected by contamination from effluent over last 15 years (Blacksmith, 2009). This has caused degradation of water quality in this water scarce semi-arid region of the country.

\section{METHODOLOGY}

\subsection{Data used}

Satellite data - Indian remote sensing satellite data (IRS LISSIII \& IV and Cartosat ) was used for land use/cover and hydrological mapping and DEM generation. Available reports and ground water data (temporal water level of 1984-2007, water quality of 1997-2006 and discharge data) from Ground water department (GWD), Rajasthan Industrial Infrastructure Corporation(RIICO), District Industries Office, Pollution Control Board, CETP etc. was collected for analysis. Drilling data of existing bore wells for 3D analysis of aquifer formation. SOI topomaps, rainfall (1984-2006), resistivity survey, pump test and well data.

\subsection{Methodology}

\subsubsection{Remote sensing \& GIS analysis}

Remotely sensed data is compatible and can be integrated with most of the other data generated from conventional and groundwater measurement system, using Geographical Information System (GIS). It provides non-invasive spatial and sptio-temporal information about surface \& subsurface of a medium. Spatial

\section{Remote sensing data interpretation \& GIS database}

Following layers were generated for input to modelling

Base Map: Using topographical map information and high resolution satellite data, road, rail, settlement, canal and drainages have been delineated.

Slope: Cartosat \& SRTM data have been used for DEM generation and slope of the study area.

Geological Map: Lithology map of the study area is prepared from the existing maps of Geological Survey of India (GSI).

Land Use / Land Cover Map: This map is prepared using temporal satellite images and change detection study is done between 1997 and 2006.

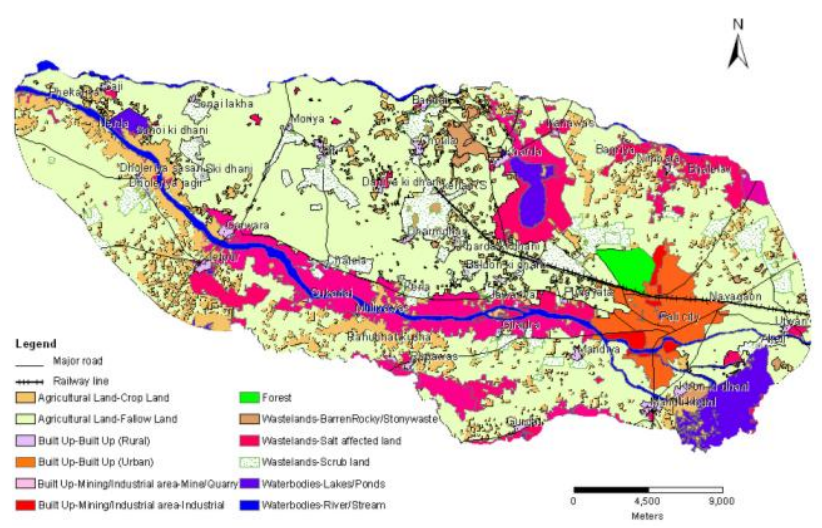

Figure-1: Land use/cover map of study area

Agriculture is the main land use category $(66.80 \%)$ out of which crop land (Rabi only) is confined to $10.28 \%$. Wasteland mainly salt affected encompasses $20.68 \%$. Waterbodies in the form of tanks and river/streams occupies $6.53 \%$ area. Remain- 
ing part is built-up land both industrial and residential. Change detection analysis carried out in $3 \mathrm{~km}$ buffer zone around Bandi river indicated areas of impact on land use/ cover particularly, agriculture activity - cropped area has reduced around $23.58 \%$ and increase in fallow land. Increase in wasteland-salt affected land \& waterbodies by $3.86 \& 3.08 \%$, respectively. Normalised difference vegetation index found to have negative correlation with pollution level.

Hydrogeological Map: The hydrogeological conditions of the terrain are depicted by the ground water potential maps, prepared by Ground Water Department, Pali. Well locations are plotted as GIS layer for depicting zoning pattern of water level and water quality. Rhyolite, granite, younger alluvium, older alluvium and phyllites form the major aquifer in this area. Borelog data have been analysed, isopach map (joining of similar lithologial unit) generated to get the thickness and multi-log 3D lithological model generated for input to hydrogeological boundaries in modelling. Aquifer cross section showing water column thickness along with strip log of bore wells indicating lithological horizons is shown in Figure-2.

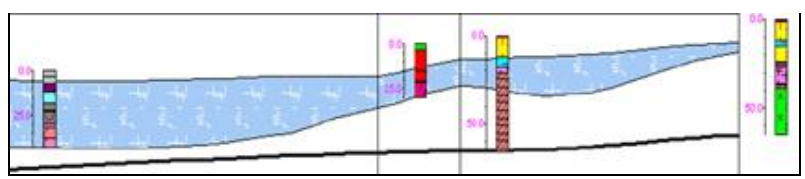

Figure-2 Cross section of aquifer along river Bandi

Pollution monitoring : The pollution of ground water is a slow but intrinsic process and it may take years together and lot of efforts to regain the natural quality of the ground water, with analysis of existing data the variation in the spatial layer and database preparation of water quality and depth of well along the polluted river. Water quality zoning for selected parameters of polluted water is done using data of ten wells.

\subsubsection{Ground water modelling}

Conceptual model: A conceptual model was developed based on the analysis of available data (litholog, GW levels, hydrogeomorphology, aquifer material). A multilayered structure based on hydrological properties was conceptualised defining the model geometry. Initial hydrological properties viz. three dimensional hydraulic conductivity, transmissivity, storage property (specific yield) were estimated along with time series rainfall, well level data. The boundary condition establishment helped in confining the model domain. DEM as upper layer and Surface generated by litholog data, minimum and maximum water levels \& maximum depth of well log formed the structure. Towards flow boundary, eastern boundary has crystalline rock (Rhyolite). North and South are having streams. Bandi river flow is modelled as river. General head boundary condition towards Eastern part signifies dam. Transport boundary condition in the form of rainfall recharge zones generated using land use, slope and vegetal cover into consideration.
Numerical modelling (Flow model): Both steady state and transient model run for the period of 10 years (1995-2005), five years water level data used for calibration and rest for validity, prediction were carried out till 2010. Steady state flow occurs when the magnitude and direction of flow is constant with time throughout the entire domain. Conversely, transient flow occurs when the magnitude and direction of the flow changes with time. This is precursor to migration study. During calibration run higher calculated values are shown above equal calculated \& observed line in the 95 confidence range for layer one (wells shown in red symbols) indicates model is over predicting.

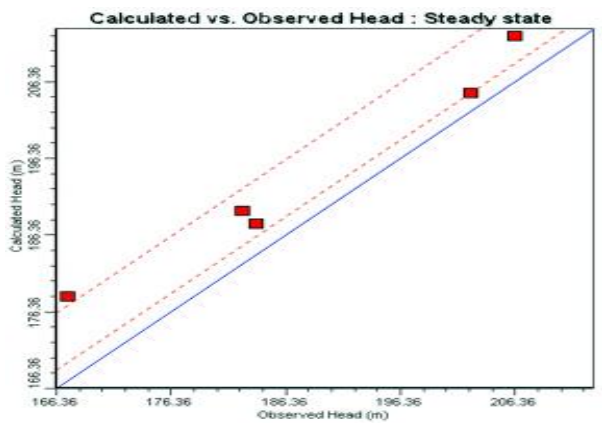

Figure-3 Comparison of calculated and observed well head

Contamination migration: General migration pathways commonly used in investigating conceptual aquifer model are the floaters (immiscible contaminants), mixers (contaminants with uniform dissolution and movement in the aquifer), and sinkers (contaminants that move vertically due to density makeup). Copper and other heavy metals which are essential nutrient to plant $\&$ animal can be toxic at higher concentration. Initial concentration of contaminant assigned in GW modelling software. Advective flow model uses particle tracking based Eulerian-lagrangian method and explicit finite-difference method for dispersion.

Fundamental difficulty in advection-dispersion modelling is both co-exist in transportation governing equations. While the miscible contaminant is transported at the same rate as that of ground water hydrodynamic dispersion is also governed by sorption property and concentration gradient of contaminant. Substantial part (sinkers) of the contaminant is likely to percolate down was also evident during the field visits.

\section{Pump test $\&$ resistivity for aquifer parameters:}

Pumping test is performed to estimate specific aquifer properties and resistivity survey carried out to get the local clay enriched zone with reduced hydraulic conductivity.

Surface geophysical method is most suitable for depth wise scanning of subsurface as input to distributed numerical model. Resistivity profiling is done to know the depth of weathered zone granite/rhyolite and slate/phyllite terrain. 


\subsection{Results \& discussion}

Pumping Test carried out at three wells in three different lithological settings shows decreasing transmissivity (952 to $493 \mathrm{~m}^{2} / \mathrm{d}$ ) from SE to NW.

Litholog data analysis shows mainly three unconfined aquifer zones viz. younger \& older alluvium and weathered/fractured granite. Withdrawal distribution in space \& time can be inferred from satellite imagery.

Groundwater velocity vectors are calculated by dividing the darcy velocity by effective porosity (smaller than total porosity due to some pores spaces containing zero seepage velocity). Pathlines are generated displaying flow path and advective ground water flow. The predominant direction towards the dam location indicates it follows the river flow direction.

Calibration and validation was done using ground water modelling software. Residual histogram uniformity indicates the calibration was optimum, however the offset exhibits need for improvement of parameters.

DEM derived from satellite helped in generating surface elevation, slope steepness $\&$ aspect for inferring surface flow $\&$ recharge.

Water quality analysis shows there has been decreasing trend in TDS \& chloride and increase in nitrate, fluoride \& havey metals during 1998-2009. Although water released for irrigation is meagre compared to canal capacity from the Hemawas dam located in eastern boundary but its return flow flushes the contaminated GW irrigated land in SE part of study area, reducing probability of their accumulation.

\section{CONCLUSIONS}

Generating reliable \& accurate information about ground water quality, integration of various techniques and availability of water related data is a essential is for addressing its pollution issue.

Surface flow is checked by Nerada dam built across river Bandi for storing monsoon run-off to enhance irrigation of that area, but it is proving to be accumulation point in absence of good rainfall \& flow in the river.

Remote sensing data is found to be very useful in defining the conceptual and setting-up of numerical model besides outflow of contaminated water affecting the land use and immensely helped in determining the sinks as waterbodies and source canal seepage.

Excessive use of chemical dyes should be restricted and should be replaced with vegetable dyes. Hotspots of dumping /active contamination were identified with certain remediation efforts, partly addressed by supply of solid waste to cement industry.
Potential solution of many $\mathrm{pH}$ related problem is installation of permeable reactive wall. Bio-sorbents developed using some natural dyes waste to filter the heavy metals \& reduction of colour in the wastewater could also be used.

\section{References}

Anderson, M.P., 1984. Ground water: Ground water transportation advection \& dispersion. National Academy Press, Washington DC, pp. 37-45.

Buselli, G., Hwang, H.S., K.Lu., 1998. Mine site Ground Water contamination mapping. Exploration geophysics, 29(3/4):296(1998).

Blacksmith Institute, 2009. In: Multi-stackholder consultation for industrial waste management in Jodhpur, Pali \& Balotra. New York, USA, pp. 20.

Brunner, P., Hendricks Franseen, H.J., Kgotlhang, L. BaucerGottwein, P., Kinzelbach, W., 2007. How can remote sensing contribute in ground water modelling? Hydrogeology Journal Vol.15(1), pp. 5-18

CGWB, 2004. Status of ground water quality and pollution in some districts of Rajasthan. Memoir - Central Ground Water Board, Jaipur.

CSE, 2006. CSE report on pollution of Bandi river due to textile industries in Pali town. Centre for Science and Environment.

Mathur, N., Bhatnagar, P., Bakre, P. Assessing mutagencity of textile dyes from Pali using Ames Biossay. Applied ecology \& environmental research. 4(1) pp 111-118. ISSN 15891623

Mahnot, S.M., Durve, V.S., 1987. Textile industry \& water pollution problem of western Rajasthan. In: Environmental degradation of western Rajasthan. pp 63-71.

Meijerink, A.M.J., 2007. IHP-VI Series on ground water no 16, UNESCO, Paris, France, SC-2007WS/43

Shenai, V.A., 1973. Chemistry of dyes and principal of dying. Sevak publication, Bombay, India.

Zheng, C., Bannet, 1995. Applied contamination modelling: Theory \& practice. John Wiley \& Sons, New York, pp. 440.

http://www.indiawaterportal.org/sites/indiawaterportal.org/file s/ground-pollute4_FULL_.pdf. (16 February 2012)

\section{Acknowledgements}

Authors are grateful to Dr. V. K. Dadhwal, Director, and Dr. Y.V.N. Krishnamurthy, Dy. Director (RSA), NRSC Hyderabad for encouragements and support. 